\title{
ECLETICA
}

www.scielo.br/eq

Volume 32, número 1, 2007

\section{Argentimetric assay of ranitidine in bulk drug and in dosage forms}

\author{
K. Basavaiah* , B.C. Somashekar \\ Department of Chemistry, University of Mysore, Manasagangotri, Mysore-570006, India \\ E-mail address:*basavaiahk@yahoo.co.in
}

\begin{abstract}
Two simple, rapid and cost-effective methods based on titrimetric and spectrophotometric techniques are described for the assay of RNH in bulk drug and in dosage forms using silver nitrate, mercury(II)thiocyanate and iron(III)nitrate as reagents. In titrimetry, an aqueous solution of RNH is treated with measured excess of silver nitrate in $\mathrm{HNO}_{3}$ medium, followed by determination of unreacted silver nitrate by Volhard method using iron(III) alum indicator. Spectrophotometric method involve the addition a known excess of mercury(II)thiocyanate and iron(III)nitrate to RNH, followed by the measurement of the absorbance of iron(III)thiocyante complex at $470 \mathrm{~nm}$. Titrimetric method is applicable over 4-30 $\mathrm{mg}$ range and the reaction stoichiometry is found to be $1: 1\left(\mathrm{RNH}: \mathrm{AgNO}_{3}\right)$. In the spectrophotometric method, the absorbance is found to increase linearly with concentration of $\mathrm{RNH}$ which is corroborated by the correlation coefficient of 0.9959 . The system obey Beer's law for 5-70 $\mu \mathrm{g} \mathrm{mL}^{-1}$. The calculated apparent molar absorptivity and sandell sensitivity values are found to be $3.27 \times 10^{3} \mathrm{~L} \mathrm{~mol}^{-1} \mathrm{~cm}^{-1}, 0.107$ $\mu \mathrm{g} \mathrm{cm} \mathrm{cm}^{-2}$ respectively. The limits of detection and quantification are also reported for the spectrophotometric method. Intra-day and inter-day precision and accuracy of the methods were evaluated as per ICH guidelines. The methods were successfully applied to the assay of RNH in formulations and the results were compared with those of a reference method by applying Student's $t$ and F-tests. No interference was observed from common pharmaceutical excipients. The accuracy of the methods was further ascertained by performing recovery tests by standard addition method.
\end{abstract}

Keywords: Ranitidine; assay; silver nitrate; pharmaceuticals; spectrophotometry; titrimetry.

\section{Introduction}

Ranitidine hydrochloride (RNH), chemically, is N, N-dimethyl-5-[2-(1-methylamino-2-nitrovinyl)-ethylthiomethyl] furfurylamine hydrochloride (Fig. 1). It is a $\mathrm{H}_{2}$ - receptor antagonist and is widely used in short term treatment of duodenal ulcer and in the management of hypersecretory conditions[1]. The drug is official in Indian Pharmacopoeia[2]. Several techniques such as proton magnetic resonance spectroscopy [3], near infrared reflectance spectroscopy[4,5], scintillation proximity assay[6], flow injection fluorimetry[7,8], polarography $[9,10]$, differential pulse polarogra- phy[11], capillary electrophoresis[12], liquid chromatography[13], high performance liquid chromatography [14-18] and kinetic spectrophotometry[19] have been reported for the determination of $\mathrm{RNH}$ in pharmaceuticals. These techniques require sophisticated instruments and expensive reagents and involve several manipulation steps.

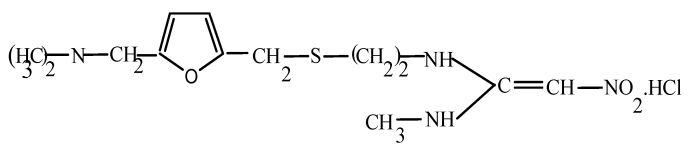

Figure 1. Structure of drug 
Literature survey revealed that the only titrimetric method[20] reported for $\mathrm{RNH}$ requires 300 $\mathrm{mg}$ of drug for each titration. There are several reports of the determination of RNH by spectrophotometry involving the use of Folin-Ciocalteu reagent[21], azine[22] and other[23] dyes, 3methyl-2-benzothiazoline hydrazone-iron (III)[24], $7,7,8,8$ tetracyanoquinodimethane[25], 2, 6dichloroquinone chlorimide[26], sodium nitrite[27], rose bengal[28], bromothymol blue[29], iodine-

Table 1. Comparison of the existing spectrophotometric methods with the proposed metho for ranitidine

\begin{tabular}{|c|c|c|c|c|}
\hline $\begin{array}{l}\text { Sl. } \\
\text { No. }\end{array}$ & Reagent/s employed & $\begin{array}{l}\text { Linear range, } \mu \mathrm{g} \mathrm{mL}^{-1}(\in, \\
\left.\mathrm{L} \mathrm{mol}^{-1} \mathrm{~cm}^{-1}\right)\end{array}$ & Remarks & Ref \\
\hline 1. & $\mathrm{~F}-\mathrm{C}$ reagent & $40-240$ & Least sensitive & 21 \\
\hline 2. & $\begin{array}{l}\mathrm{KMnO}_{4} / \mathrm{NBS} \text {-azine } \\
\text { dyes }\end{array}$ & $\begin{array}{l}5-30\left(5.2 \times 10^{3}\right) \\
0.5-4\left(1.89 \times 10^{4}\right) \\
0.4-2.8\left(4.2 \times 10^{4}\right) \\
0.4-2.8\left(7.2 \times 10^{4}\right)\end{array}$ & Involves extraction & 22 \\
\hline 3. & $\begin{array}{l}\text { Cerium(IV)- } \\
\text { chromotrope } 2 \mathrm{R} \\
\text { Cerium(IV)- } \\
\text { rhodamine 6G }\end{array}$ & $0.1-2.6\left(1.74 \times 10^{5}\right)$ & $\begin{array}{l}\text { Involve boiling for } 5 \\
\min \end{array}$ & 23 \\
\hline 4. & Iron-(III) MBTH & $5-18$ & $\begin{array}{l}\text { Involves } 30 \mathrm{~min} \\
\text { contact time, uses an } \\
\text { expensive reagent }\end{array}$ & 24 \\
\hline 5. & TCQD & $1-6$ & $\begin{array}{l}\text { Requires } \\
\text { thermostating at } 70^{\circ} \mathrm{C} \\
\text { for } 10 \mathrm{~min}\end{array}$ & 25 \\
\hline 6. & $\mathrm{DCBC}$ & $10-50$ & $\begin{array}{l}\text { Involves boiling for } 20 \\
\text { min }\end{array}$ & 26 \\
\hline 7. & $\mathrm{NaNO}_{2}$ & $0.3-12 \mathrm{mg} \mathrm{mL}^{-1}$ & $\begin{array}{l}\text { Involves flow } \\
\text { injection automated } \\
\text { assembly, least } \\
\text { sensitive }\end{array}$ & 27 \\
\hline 8. & Rose bengal & $2-12$ & $\begin{array}{l}\text { Involves extraction } \\
\text { and strict } \mathrm{pH} \text { control }\end{array}$ & 28 \\
\hline 9. & Bromothymol blue & $1-20$ & $\begin{array}{l}\text { Involves extraction } \\
\text { and strict } \mathrm{pH} \text { control }\end{array}$ & 29 \\
\hline 10. & $\mathrm{~K} \mathrm{IO}_{3}{ }^{-}$starch & $10-80\left(1.8 \times 10^{3}\right)$ & & 30 \\
\hline 11. & $\mathrm{KIO}_{3}$ - DCF & $5-50\left(3.9 \times 10^{3}\right)$ & $\begin{array}{l}\text { Requires strict } \mathrm{pH} \\
\text { control }\end{array}$ & 31 \\
\hline 12. & $\mathrm{Hg}(\mathrm{SCN})_{2}$-iron(III) & $5-70\left(3.27 \times 10^{3}\right)$ & $\begin{array}{l}\text { Applicable to wide } \\
\text { dynamic linear range }\end{array}$ & $\begin{array}{l}\text { Present } \\
\text { method }\end{array}$ \\
\hline
\end{tabular}


starch[30] and iodate-dichlorofluorescein[31]. These methods are based on redox, coupling, charge-transfer complexation, nitrosation and ionpair complexation reactions. However, the reported spectrophotometric methods suffer from one or the disadvantage such as poor sensitivity, a complicated and time consuming procedure, heating or extraction step or the need for expensive or undesirable chemicals (Table 1).

In this communication, we demonstrate the use of titrimetric and spectrophotometric techniques for the determination of RNH. These would overcome the problems encountered in the methods previously mentioned. The titrimetric method involves the addition of measure excess of silver nitrate to RNH in nitric acid medium and back titrating the unreacted silver nitrate with ammonium thiocyanate in the presence of iron(III) alum as the indicator. The spectrophotometric method is based on the displacement of thiocyanate from mercury(II)thiocyanate by the dissociated chloride ion of RNH and liberated thiocyanate reacts with iron(III) to form red colored complex and measurement of complex at $470 \mathrm{~nm}$.

\section{Experimental details}

\section{Apparatus}

A Systronics model 106 digital spectrophotometer with $1-\mathrm{cm}$ matched quartz cells was used for all absorbance measurements.

\section{Reagents and materials}

All chemicals used were of analytical grade. Double distilled water, second time distilled over alkaline potassium permanganate was used throughout.

Silver nitrate solution. An approximately $0.01 \mathrm{~mol}$ $\mathrm{L}^{-1}$ silver nitrate solution was prepared by dissolving about $0.42 \mathrm{~g}$ of $\mathrm{AgNO}_{3}$ (Sarabhai Chemicals, Vadodara) in water and diluting to volume in a $250 \mathrm{~mL}$ standard flask. The solution was standardized against sodium chloride[32]. The solution was stored in amber colored bottle and kept in dark untill use. Working solutions were prepared by appropriate dilution when required.

Ammonium thiocyanate solution.An approximately $0.01 \mathrm{~mol} \mathrm{~L}^{-1}$ ammonium thiocyanate solution was prepared by dissolving about $0.38 \mathrm{~g}$ of chemical (Ranbaxy Chemicals, New Delhi, India) in water and diluting to $500 \mathrm{~mL}$ in a volu- metric flask, and standardized by Volhard method[32] and used in titrimetric analysis.

Iron(III) indicator.Prepared by dissolving about $10 \mathrm{~g}$ of ferric ammonium sulphate in 100 $\mathrm{mL}$ of $1: 1$ nitric acid and boiling the solution till the oxides of nitrogen were expelled.

Iron (III) nitrate reagent. Prepared by dissolving $15.1 \mathrm{~g}$ of chemical (BDH) in $45 \mathrm{~mL}$ of $72 \%$ perchloric acid and diluting to $100 \mathrm{~mL}$ with water. This solution was $0.375 \mathrm{~mol} \mathrm{~L}^{-1}$ in iron (III) and $5.25 \mathrm{~mol} \mathrm{~L}^{-1}$ in perchloric acid, and used in spectrophotometric study.

Mercury(II)thiocyanate solution. A saturated solution of mercury(II) thiocayanate solution (Loba Chemie, Mumbai) in methanol was prepared in the usual way. Chloride free nitrobenzene was used for titrimetric work.

1:1 Nitric acid. A 1:1 nitric acid (S.D. Fine Chem. Boisar. India) was prepared by diluting nitric acid with equal volume of water.

Standard RNH solution. Pharmaceutical grade $\mathrm{RNH}$ reported to be $99.8 \%$ pure was received from Glaxo Smithkline Pharmaceuticals ltd., Nasik, India as gift and was used as received. A stock standard solution of RNH containing 2 $\mathrm{mg} \mathrm{mL}^{-1}$ was prepared by dissolving $500 \mathrm{mg}$ of sample in water and diluting to $250 \mathrm{~mL}$ in a volumetric flask. For spectrophotometric work this concentration was diluted stepwise to get a working solution of $200 \mu \mathrm{g} \mathrm{mL}^{-1}$.

Sample solution. A quantity of finely ground tablet powder or an aliquot of injection solution equivalent to $200 \mathrm{mg}$ of RNH was accurately transferred into a $100 \mathrm{~mL}$ calibrated flask, $60 \mathrm{~mL}$ of water added and shaken for $20 \mathrm{~min}$. Then the volume was made up to the mark with water, mixed well, and filtered using a Whatman No 42 filter paper. First $10 \mathrm{~mL}$ portion of the filtrate was discarded and a suitable aliquot of the subsequent portion $\left(2 \mathrm{mg} \mathrm{mL}^{-1} \mathrm{RNH}\right)$ was taken for assay by titrimetric procedure. The filtrate(tablet extract/injection) was diluted appropriately to get $200 \mu \mathrm{g} \mathrm{mL}^{-1}$ solutions for spectrophotometric determination.

Dosage forms. The fallowing dosage forms were purchased from local commercial sources and subjected to analysis.

Zintac tablets $(300 \mathrm{mg})$ and ranitidine injections $(25 \mathrm{mg}$ ) both from Torrent Pharmaceuticals, Ltd., India, and aciloc tablets $(150 \mathrm{mg})$ and injections $(25 \mathrm{mg}$ ) from Glaxo smithkline Pharma. Ltd., India. 


\section{Procedures}

Titrimetry.An aliquot measuring $15 \mathrm{~mL}$ of standard solution containing 4-30 mg RNH was measured accurately into a $100 \mathrm{~mL}$ Erlenmeyer flask and acidified with $2 \mathrm{~mL}$ of 1:1 nitric acid. Then, $10 \mathrm{ml}$ of $0.01 \mathrm{~mol} \mathrm{~L}^{-1}$ silver nitrate was introduced by means of a pipette and shaken thoroughly for a min. Finally, $2 \mathrm{~mL}$ of nitrobenzene were added and shaken vigorously until the silver chloride was coagulated; $0.5 \mathrm{~mL}$ of iron(III) alum indicator was added and the residual silver nitrate was titrated with standard $0.01 \mathrm{~mol} \mathrm{~L}^{-1}$ ammonium thiocyanate solution to a permanent red color end-point. A blank was run in the same way.

The drug content was calculated using the formula

\section{$\underline{\text { (B-S) R Mw }}$}

$\mathrm{n}$

where B is the volume of thiocyanate consumed in the blank titration,

$\mathrm{S}$ is the volume of thiocyanate consumed in the test sample titration,

$\mathrm{R}$ is the molarity of thiocyanate solution,

Mw is the relative molecular mass of drug and ' $n$ ' is the number of moles of silver nitrate reacting with one mole of drug.

Spectrophotometry. Into a series of $10 \mathrm{~mL}$ standard flasks were transferred $0,0.25,0.5,1.0$, ..... $3.5 \mathrm{~mL}$ of $200 \mu \mathrm{g} \mathrm{mL}^{-1}$ of RNH solution by means of a microburette; $2 \mathrm{~mL}$ of mercury(II) thiocyanate solution and $1 \mathrm{~mL}$ of iron (III) nitrate reagent were added and diluted to volume with water. The solution was mixed well and absorbance measured against the reagent blank at $470 \mathrm{~nm}$ after $10 \mathrm{~nm}$. The increase in absorbance was plotted against the RNH concentration. The concentration of the unknown was read from the calibration graph or computed from the linear regression equation.

Convenient aliquot of tablet/injection solutions $\left(2 \mathrm{mg} \mathrm{mL}^{-1}\right.$ for titrimetry and $200 \mu \mathrm{g}$ $\mathrm{mL}^{-1}$ for spectrophotometry were subjected to analysis by the above procedures.

\section{Results and Discussions}

Majority of the pharmaceutically important organic compounds are prepared as hydrochlorides and some have been assayed by determining their chloride content. No literature reports were found describing the assay of RNH via determination of its chloride content. The present work deals with the determination of RNH by two methods. In titrimetry, the drug was determined by measuring its chloride content by Volhard method[32]. The spectrophotometric procedure involves the reaction of chloride with mercury (II) thiocyanate to form soluble mercury(II)chloride with the liberation of thiocyanate ions which then react with iron (III) to form the familiar red colour which can be measured at $470 \mathrm{~nm}$.

\section{Method development}

Titrimetry

Volhard method has been used for the indirect determination of chloride in diverse matrices including pharmaceuticals[33,34]. In the present method, a known excess of standard silver nitrate solution is added to the drug solution and the excess back titrated with standard thiocyanate solution using iron(III) as indicator and in the presence of nitrobenzene. RNH in aqueous solution ionizes to give the protonated drug moiety and chloride ion, the latter being reacted with $\mathrm{Ag}^{+}$as follows:

$$
\begin{aligned}
& \mathrm{RNH} \cdot \mathrm{HCl} \rightleftharpoons \mathrm{RNH}^{+}+\mathrm{Cl}^{-} \\
& \mathrm{Cl}^{-}+\mathrm{Ag}^{+} \text {(excess) } \rightleftharpoons \mathrm{AgCl}_{(\mathrm{s})+\mathrm{Ag}^{+} \text {(unreacted) }}^{\rightleftharpoons} \\
& \mathrm{Ag}^{+} \text {(unreacted) }+\mathrm{SCN}^{-} \rightleftharpoons \mathrm{AgSCN}(\mathrm{s})
\end{aligned}
$$

Iron (III) serves as the indicator imparting a red color to the solution to the first excess of thiocyanate ion:

$$
\mathrm{Fe}^{3+}+\mathrm{SCN}^{-} \rightleftharpoons \mathrm{Fe} \mathrm{SCN}^{2+} \text { (red) }
$$

A $0.5 \mathrm{~mL}$ of indicator solution and $2 \mathrm{~mL}$ of $1: 1$ nitric acid in a total volume of about $30 \mathrm{~mL}$ gave satisfactory results. $\mathrm{AgCl}$ is more soluble than $\mathrm{AgSCN}$ and hence leads to low values of chloride analysis and drug recovery. This source of error is circumvented by the addition of $2 \mathrm{~mL}$ of nitrobenzene and shaking the reaction mixture thoroughly before the back titration of the residual silver nitrate[35]. The calculated molar ratio of 1:1 between $\mathrm{RNH}$ and $\mathrm{AgNO}_{3}$ is consistent with the reaction scheme shown above and was used for calculations.

\section{Spectrophotometry}

There are several reports on the spectrophotometric determination of chloride in various matrices[36-40]. One of the most widely used methods for the determination of chloride at low 
levels consists of spectrophotometric measurement at $470 \mathrm{~nm}$ of the coloured iron (III) thiocyanate complex[36-40]. In the proposed method, the dissociated chloride of $\mathrm{RNH}$ displace thiocyanate from mercury(II)thiocyanate and the liberated thiocyanate reacts with iron(III) to form red coloured complex FeSCN ${ }^{2+}$ which is measured at $470 \mathrm{~nm}$. The essential reaction involved are:

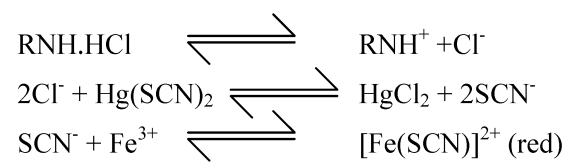

The absorbance of the coloured complex measured is a quantitative measure of the concentration of RNH. The wavelength of maximum absorption was found at $470 \mathrm{~nm}$ which is in agreement with the earlier observations in perchloric acid medium [36,37]. The linear increase in absorbance at $470 \mathrm{~nm}$ with increase in $\mathrm{RNH}$ concentration showed that the protonated drug moiety, $\mathrm{RNH}^{+}$had no effect on the complex formation and its colour stability.

Since the method is essentially the measurement of iron (III) thiocyanate complex, different variables like the kind of acid, source of iron (III), excess of thiocyanate and contact time which influence the colour intensity and the stability were optimised.

The effect of varying concentrations of $\mathrm{HNO}_{3}, \mathrm{HClO}_{4}$ and $\mathrm{H}_{2} \mathrm{SO}_{4}$ on the absorbance was studied. $\mathrm{HNO}_{3}, \mathrm{HClO}_{4}$ gave similar sensitivities while the use of $\mathrm{H}_{2} \mathrm{SO}_{4}$ led to a much lower sensitivity. Perchloric acid was chosen as the reaction medium in preference to nitric acid for lower blank absorbance, and because low and erratic results were obtained with nitric acid. The effective perchloric acid concentration employed was about $0.5 \mathrm{~mol} \mathrm{~L}^{-1}$.

Different sources of iron (III) may be used, such as iron(III) nitrate[37], iron (III) ammonium sulphate[39] perchlorate[36]. Iron(III)nitrate was preferred to the other iron (III) salts, because the procedure using iron (III) nitrate was found to be more sensitive and more linear than that using iron (III) ammonium sulphate and because of high chloride content of iron (III) perchlorate. One milliliter of iron (III) nitrate solution in a total volume of $10 \mathrm{~mL}$ was found adequate. Higher concentrations were found to increase the absorbance only slightly but larger blanks were obtained. With increasing concentrations of mercury (II)thiocyanate, increase in absorbance was only marginal. Two $\mathrm{mL}$ of reagent solution in a total volume of $10 \mathrm{~mL}$ was found sufficient.

Different solvents such as ethanol[37], methanol[40] and water[36] have been used to prepare mercury(II)thiocyanate reagent. High sensitivity was obtained when methanolic solution was used. Moreover, large amounts of ethanol are reported to bleach the iron(III)thiocyanate complex[36]. The reaction is fast and colour development is considered complete in $5 \mathrm{~min}$ at room temperature $\left(30 \pm 2^{\circ} \mathrm{C}\right)$. The colour remained stable up to $6 \mathrm{~h}$.

\section{Method Validation \\ Quantitative parameters}

Titrimetry was found applicable in the range 4-30 mg, outside which the results were not satisfactory. The relationship between the titration end-point obtained by the proposed titrimetric method and the drug amount was examined. The linearity between the amount of drug and titration end-point is apparent form the calculated best-fit line via linear least squares treatment. The calculated value of $r(0.9974)$ shows that the reaction between $\mathrm{AgNO}_{3}$ and $\mathrm{RNH}$ proceeds stoichiometrically in the ratio $1: 1$.

Under the described experimental conditions, a linear correlation was obtained between absorbance (A) and the concentration (C) of RNH over the range 5-70 $\mu \mathrm{g} \mathrm{mL}^{-1}$. The linear regression equation was:

$$
\mathrm{A}=0.0046+0.0091 \mathrm{C} \quad(\mathrm{r}=0.9959)
$$

The apparent molar absorptivity and Sandell's sensitivity were $3.27 \times 10^{3} \mathrm{~L} \mathrm{~mol}^{-1} . \mathrm{cm}$ and $0.107 \mu \mathrm{g} \mathrm{cm}^{-2}$, respectively.

The limits of detection (LOD) and quantification (LOQ) were calculated according to the current ICH guidelines (41) using the fallowing formulae:

$$
\mathrm{LOD}=\frac{3.3 \sigma}{\mathrm{S}} \text { and } \mathrm{LOQ}=\frac{10 \sigma}{\mathrm{S}}
$$

where $\sigma$ is the standard deviation of seven reagent blank determinations and $\mathrm{S}$ is the slope of the calibration curve. The calculated LOD and LOQ were found to be 0.86 and $2.61 \mu \mathrm{g} \mathrm{mL}^{-1}$, respectively. 


\section{Accuracy and precision}

The accuracy of the methods was evaluated by analyzing the pure drug at different levels and the precision was established by determining the relative standard deviation of seven replicate analysis on the same solution containing three different levels of the drug. The percentage recovery, the RSD and the range of error (\%) at $95 \%$ confidence level indicate the reasonable accuracy and precision of the methods.

The values of between-day RSD for three different concentrations of drug, obtained from determinations carried out over a period of five days were between $2.5-4.0 \%$ indicating the reasonable repeatability of the methods (Table 2).

The ruggedness/robustness of the methods was assessed by calculating the RSD for results obtained by performing the analysis using three different instruments and by three different persons. The inter-instrumental RSD values were in the range of $3.5-5.5$ whereas the inter-personal RSD values varied from 2.6-4.2 $(n=3$ in both instances) for three concentrations employed for accuracy and intra-day precision studies.

\section{Interferences}

Bromide ion interferes in any quantity. Higher concentration of sulphates and phosphates bleach the colour of iron (III) thiocyanate complex. Large amounts of ethyl and isopropyl alcohols are reported to impart a yellowish brown colour to the complex. But none of the above substances is present in either the reagents employed or the formulations analysed, and hence the methods are devoid of error due to them.
Application to analysis of tablets and injections

The proposed methods were applied to the determination of $\mathrm{RNH}$ in tablets and injections. The results presented in Table 3 indicate that excipients present in formulations do not interfere with the visual end-point detection and spectrophotometric measurement of iron(III)thiocyanate complex. The same batch of tablets were also assayed by a reference method[2] which consisted of the measurement of the absorbance of the tablet extract or injection solution in $0.1 \mathrm{~mol} \mathrm{~L}^{-1}$ hydrochloric acid at 225 $\mathrm{nm}$, and statistical analysis (t- and F-test) of the results obtained by the proposed methods and the reference method showed no significant difference in the performance of the two methods.

\section{Recovery study}

To confirm the accuracy and reliability of the methods recovery test was performed via standard-addition procedure. Pre-analysed tablet powder/injection solution containing a known and definite amount of RNH was spiked with pure drug at three levels and the total was found by the proposed methods. The percent recovery of added pure drug which lies between 98.2 and 103.6 (Table 4) reveals that the procedures are free from interference from usual tablet excipients like talc, starch, state, alginate, gumacacia, calcium gluconate, sucrose, etc.

\section{Conclusions}

The method using $\mathrm{AgNO}_{3}$ is indirect and is based on the determination of the chloride of

Table 2. Accuracy and precision of the methods

\begin{tabular}{|c|c|c|c|c|c|c|c|c|c|c|c|}
\hline \multicolumn{6}{|c|}{ Titrimetric method } & \multicolumn{6}{|c|}{ Spectrophotometric method } \\
\hline $\begin{array}{l}\text { RNH } \\
\text { taken, } \\
\mathrm{mg}\end{array}$ & $\begin{array}{l}\text { RNH } \\
\text { found*, } \\
\mathrm{mg}\end{array}$ & $\begin{array}{l}\text { Error, } \\
\%\end{array}$ & $\begin{array}{l}\mathrm{RSD}^{\mathrm{a}} \text {, } \\
\%\end{array}$ & $\begin{array}{l}\mathrm{RSD}^{\mathrm{b}}, \\
\%\end{array}$ & $\begin{array}{l}\text { Range } \\
\text { of } \\
\text { error, } \\
\%\end{array}$ & $\begin{array}{l}\text { RNH } \\
\text { taken, } \\
\mu \mathrm{g} \\
\mathrm{mL}^{-1}\end{array}$ & $\begin{array}{l}\text { RNH } \\
\text { found*, } \\
\mu \mathrm{g} \mathrm{mL} \\
1\end{array}$ & $\begin{array}{l}\text { Error, } \\
\%\end{array}$ & $\begin{array}{l}\mathrm{RSD}^{\mathrm{a}} \text {, } \\
\%\end{array}$ & $\begin{array}{l}\mathrm{RSD}^{\mathrm{b}}, \\
\%\end{array}$ & $\begin{array}{l}\text { Range } \\
\text { of } \\
\text { error, } \\
\%\end{array}$ \\
\hline 5 & 4.86 & 2.8 & 1.29 & 3.2 & \pm 1.29 & 20 & 20.53 & 2.65 & 1.10 & 4.0 & \pm 1.10 \\
\hline 15 & 14.68 & 2.13 & 1.65 & 2.5 & \pm 1.64 & 40 & 39.02 & 2.45 & 0.97 & 2.9 & \pm 0.97 \\
\hline 25 & 24.26 & 2.96 & 0.94 & 2.8 & \pm 0.95 & 60 & 58.69 & 2.18 & 0.97 & 3.8 & \pm 0.96 \\
\hline
\end{tabular}


Table 3. Results of determination of RNH in tablets

\begin{tabular}{|c|c|c|c|c|}
\hline \multirow{2}{*}{$\begin{array}{l}\text { Tablet/injection } \\
\text { brands }^{\psi}\end{array}$} & \multirow{2}{*}{$\begin{array}{l}\text { Label } \\
\text { claim, } \\
\mathrm{mg} / \mathrm{tablet} \\
\text { or } \mathrm{mL}\end{array}$} & \multicolumn{2}{|c|}{$\%$ found $* \pm S D$} & \multirow[b]{2}{*}{$\begin{array}{l}\text { Reference } \\
\text { method }\end{array}$} \\
\hline & & Titrimetry & $\begin{array}{l}\text { Spectrophoto } \\
\text { metry }\end{array}$ & \\
\hline Tablets & 300 & $98.6 \pm 1.01$ & $101.6 \pm 1.02$ & $99.71 \pm 1.36$ \\
\hline $\operatorname{Zintac}^{\mathrm{a}}$ & & $\begin{array}{l}\mathrm{t}=1.47 \\
\mathrm{~F}=1.81\end{array}$ & $\begin{array}{l}t=2.52 \\
F=1.78\end{array}$ & \\
\hline Aciloc $^{b}$ & 150 & $\begin{array}{l}101.8 \pm 1.02 \\
\mathrm{t}=1.32 \\
\mathrm{~F}=1.04\end{array}$ & $\begin{array}{l}100.4 \pm 1.16 \\
\mathrm{t}=3.25 \\
\mathrm{~F}=1.24\end{array}$ & $102.66 \pm 1.04$ \\
\hline Injections & & $99.8 \pm 0.78$ & $99.1 \pm 1.34$ & $101.75 \pm 1.26$ \\
\hline Ranitidine $^{\mathrm{a}}$ & 25 & $\begin{array}{l}\mathrm{t}=3.02 \\
\mathrm{~F}=2.61\end{array}$ & $\begin{array}{l}\mathrm{t}=3.22 \\
\mathrm{~F}=1.13\end{array}$ & \\
\hline Aciloc $^{\mathrm{b}}$ & 25 & $\begin{array}{l}100.5 \pm 0.95 \\
t=1.92 \\
F=1.24\end{array}$ & $\begin{array}{l}98.4 \pm 0.52 \\
\mathrm{t}=1.76 \\
\mathrm{~F}=4.16\end{array}$ & $99.28 \pm 1.06$ \\
\hline
\end{tabular}

* Average of five determinations;

${ }^{*}$ Marketed by: a. Torrent Pharmaceuticals Ltd.; b. Glaxo SmithKline Pharm Ltd.

Tabulated t-value at $95 \%$ confidence level is 2.77 . Tabulated F-value at $95 \%$ confidence level is 6.39

Table 4. Results of recovery test

\begin{tabular}{|c|c|c|c|c|c|c|c|c|}
\hline \multirow{2}{*}{$\begin{array}{l}\text { Formulation } \\
\text { examined }\end{array}$} & \multicolumn{4}{|c|}{ Titrimetry } & \multicolumn{4}{|c|}{ Spectrophotometry } \\
\hline & $\begin{array}{l}\text { RNH } \\
\text { in } \\
\text { tablet, } \\
\mathrm{mg}\end{array}$ & $\begin{array}{l}\text { Pure } \\
\text { RNH } \\
\text { added, } \\
\text { mg }\end{array}$ & $\begin{array}{l}\text { Total } \\
\text { found, } \\
\mathrm{mg}\end{array}$ & $\begin{array}{l}\text { Recovery* } \\
\text { of pure } \\
\text { RNH } \\
\text { added, \% }\end{array}$ & $\begin{array}{l}\text { RNH } \\
\text { in } \\
\text { tablet, } \\
\mu \mathrm{g} \\
\mathrm{mL}^{-1}\end{array}$ & $\begin{array}{l}\text { Pure } \\
\text { RNH } \\
\text { added, } \\
\mu \mathrm{g} \mathrm{mL}^{-} \\
1\end{array}$ & $\begin{array}{l}\text { Total } \\
\text { found, } \\
\mu \mathrm{g} \mathrm{mL}^{-} \\
1\end{array}$ & $\begin{array}{l}\text { Recovery* } \\
\text { of pure } \\
\text { RNH } \\
\text { added, \% }\end{array}$ \\
\hline Aciloc (150 & 10.18 & 5 & 15.26 & 101.6 & 20.08 & 10 & 30.44 & 103.6 \\
\hline \multirow[t]{2}{*}{$\mathrm{mg})$} & 10.18 & 10 & 20.40 & 102.2 & 20.08 & 20 & 40.04 & 99.8 \\
\hline & 10.18 & 15 & 25.21 & 100.2 & 20.08 & 40 & 60.20 & 100.3 \\
\hline Injection & 10.05 & 5 & 15.03 & 99.6 & 19.68 & 10 & 29.89 & 102.1 \\
\hline Aciloc & 10.05 & 10 & 19.89 & 98.4 & 19.68 & 20 & 39.32 & 98.2 \\
\hline$(25 \mathrm{mg})$ & 10.05 & 15 & 25.25 & 101.3 & 19.68 & 40 & 59.76 & 100.2 \\
\hline
\end{tabular}

* Mean value of three determinations. 
the dissociated RNH in solution. The method is rapid, covers a wide range $(4-30 \mathrm{mg})$ of determination and employed unreduced RNH for assay. The spectrophotometric method is reasonably sensitive $\left(\in=3.27 \times 10^{3} \mathrm{~L} \mathrm{~mol}^{-1} \mathrm{~cm}^{-1}\right)$ but uses a novel reaction. Applicable over a wide linear dynamic concentration range, it involves the measurement of highly coloured species which can be regarded as an additional advantage.

The titrimetric method calls for exercising care while handling nitrobenzene which is appreciably toxic. Similar care is needed when mercury(II) thiocyanate is used in the spectrophotometric method. But, both methods are free from interference from concomitant substances. However, the serious limitations of both procedures is the lack of specificity, since the methods can be used only when it is absolutely certain that all the chloride ion being determined comes from $\mathrm{RNH}$ in question. The applications of these methods are usually restricted to quality control procedures and to the analysis of solution and tablets containing no interfering chloride.

\section{Acknowledgements}

The authors express their gratitude to the Quality Control Manager, Glaxo SmithKline Pharmaceuticals, Nasik, India, for providing pure ranitidine as gift. One of the authors (BCS) thanks the authorities of the University of Mysore, Mysore, for research facilities.

Received 25 September 2006. Accepted 07 February 2007.

\section{References}

[1] J.F.E. Reynolds, A. Martizdale, In: The Extra Pharmacopoeia, The Pharmaceutical Press, London, $31^{\text {st }}$ ed.,1996, pp. 1231.

[2] The Indian Pharmacopeia The Controller of Publications, Ministry of Health and Family Welfare, Govt. of India, New Delhi, 1996, pp. 659.

[3] T. Ozden, A. Ungovmus, A. Tosun, S. Erasan, Spectroscop. Lett., 30 (1997) 835.

[4] Q. Wang, S. Delerus, J. Near Infrared Spectroscop., 6 (1998) 223.

[5] E. Dreassi, G. Caramelli, P. Corti, P.L. Perruccio, S. Lonardi, Analyst, 121 (1996) 219.

[6] S. Fenwick, W.N. Jenner, P. Linacre, R.M. Rooney, S.A. Ring, Anal. Proc., 31 (1994) 103.
[7] C. Lopez - Erroz, P. Vinas, N. Campillo, M. Hernandez Cardoba, Analyst, 121 (1996) 1043.

[8] N.W. Barnett, B.J. Hindson, S.W. Lewis, Anal. Chim. Acta, 384 (1999) 151.

[9] P. Richter, M.I. Toral, F. Munoz-Varzas, Analyst, 119 (1994) 1371.

[10] M. D. Zamerreno, J. Hernandez-Mendez, A. S. Perez, Anal. Chim. Acta, 176 (1985) 279.

[11] P.S. Sankar, S.J. Reddy, Indian J. Pharm Sci. 51 (1989) 263.

[12] M.A. Kelly, K.D. Altria, C. Grace, B.J. Clark, J. Chromatogr., 798 (1996) 297.

[13] H.Y. Aboul-Enien, M. Rafiqui-Islam, Toxicol. Environ. Chem., 29 (1990) 47.

[14] G. Bettermann, S. Cabrera, S. Heizenroeder, D. Lubda, Labor Praxis, 22 (1998) 30.

[15] G.L. Iloyer, J. Le Doux, P.E. Nolan Jr., J. Liq. Chromatogr., 18 (1995) 1239.

[16] C.A. Lau-Cam, M. Rahman, R.W. Ross, J. Liq. Chromatogr., 17 (1994) 1089.

[17] V. Das Gupta, Drug Dev. Ind. Pharm., 14 (1988) 1647.

[18] N. Beaulieu, P.M. Lacroix, R.W. Sears, E.G. Lovering, J. Pharm. Sci., 77 (1988) 889.

[19] E.M. Hassan, F. Belal, J. Pharm. Biomed. Anal., 27 (2002) 31

[20] Z. Atkosar, Acta Pharm. Turc., 31(1989) 139.

[21] K. Basavaiah, P. Nage Gowda, Indian Pharmacist, 3 (24) (2004) 60.

[22] C.S.P. Sastry, S.G. Rao, J.S.V.M.L. Rao, P.Y. Naidu, Anal. Lett. 30 (1997) 2377.

[23] A.S. Amin, I.S. Ahmed, H.A. Dessouki, E.A. Gouda, Spectrochimica Acta Part A, 59 (2003) 695.

[24] E. V. Rao, J. J. Rao, S.S.N. Murthy, G. R. Rao, Indian J. Pharm, Sci., 49 (1987) 143.

[25] S. Al. Ghannam, F. Belal, J. AOAC Intl., 85 (2002) 1003.

[26] J. Emmanuel, S.D. Haldankar, Indian Drugs, 26 (1989) 249.

[27] S.S.M. Hassan, M.H.M. Mahamoud, A.H.M. Othman, Anal. Chim. Acta, 332 (1996).

[28] K.N. Raut, S.D. Sabnis, Indian J. Pharm Sci., 49 (1987) 65.

[29] Y. Ozsoy, B. Guvner, Acta Pharm. Turc., 29 (1987) 13.

[30] K. Basavaiah, P. N. Gowda, Indian Pharmacist, 2(14) (2003) 75.

[31] K. Basavaiah, P. N. Gowda, Indian J. Chem. Technol., 11 (2004) 11.

[32] A.I. Vogel, "A Text Book of Quantitative Inorganic Analysis", $5^{\text {th }}$ edn., ELBS

London, 1991, p. 349. 353.- $3^{\text {rd }}$ edn., ELBS, London, 1969, p. 78 .

[33] C.H. Wilkinson, R. Cole, J. Hosp. Pharm., 26 (1969) 45.

[34] H. Jin, T. Yao, F. Hauxue, 10 (1982) 189.

[35] J.R. Caldwell, H.V. Moyer, Ind. Eng. Chem. Anal., Ed., 7 (1935) 38.

[36] D.M. Zall, D. Fisher, M.Q. Garmer, Anal. Chem., 28 (1956) 1665.

[37] T.M. Florence, Y.J. Farrar, Anal. Chim. Acta, 54 (1971) 373.

[38] R. Krishnamurthy, K.A. Bhagawat, Indian J. Exptl. Biol., 28 (1990) 198.

[39] O.W. Lau, C.S. Mok, J. Sci. Food. Agri., 31 (1980) 1275.

[40] M.A. Herrero, J. Atiemza, R. P. Maquieira, Analyst, 117 (1992) 1019.

[41] International Conference on Hormonisation of Technical Requirements for Registration of Pharmaceuticals for Human Use, ICH Harmonised Tripartite Guideline, Validation of Analytical Procedures: Text and Methodology Q2(R 1), Complementary Guideline on Methodology dated 06 November 1996, incorporated in November 2005, London. 